\title{
Is There a Role for Bismuth in Diarrhea Management?
}

\author{
Helen Senderovich, M.D., M.C.F.P. (C.O.E.) (P.C.) ${ }^{1,2 *}$ and Megan Vierhout, \\ M.Sc., B.Sc. (Hons.) $)^{1,3}$ \\ ${ }^{\prime}$ Geriatrics $\mathcal{E}^{2}$ Pain Medicine E Palliative Care Physician, Baycrest Health Sciences, Toronto, Ontario, \\ Canada; 'Assistant Professor at the Department of Family and Community Medicine, Division of \\ Palliative Care, University of Toronto, Toronto, Ontario, Canada; and ${ }^{3}$ McMaster University, Faculty of \\ Health Sciences, Hamilton, Ontario, Canada
}

\begin{abstract}
Diarrhea, an illness of both the developed and developing world, involves the burdensome characteristics of frequent bowel movements, loose stools, and abdominal discomfort. Diarrhea is a long-standing challenge in palliative care and can have a myriad of causes, making symptomatic treatment pertinent when illness evaluation is ongoing, when there is no definitive treatment approach, or when effective treatment cannot be attained. Symptomatic therapy is a common approach in palliative care settings. Bismuth is a suitable agent for symptomatic therapy and can be effectively employed for management of chronic diarrhea. The objective of this narrative review is to examine the role of bismuth in management of diarrheal symptoms. To explore this, PubMed (including Medline) and Embase were used to search the existing literature on bismuth and diarrhea published from 1980 to 2019. It was found that bismuth has potential utility for diarrheal relief in multiple settings, including microscopic colitis, traveler's diarrhea, gastrointestinal infection, cancer, and chemotherapy. It also has great potential for use in palliative care patients, due to its minimal side effects. Overall, the antisecretory, anti-inflammatory, and antibacterial properties of bismuth make it a suitable therapy for symptomatic treatment of diarrhea. The limited range of adverse side effects makes it an appealing option for patients with numerous comorbidities. Healthcare providers can explore
\end{abstract}

\footnotetext{
Abbreviations: ATP, adenosine triphosphate; BM, bowel movements; BSS, bismuth subsalicylate; C. difficile, Clostridium difficile; E. coli, Escherichia coli; LTC, long-term care; MC, microscopic colitis; PC, palliative care; RDB, randomized double-blind.
}

Citation: Senderovich H, Vierhout M. Is There a Role for Bismuth in Diarrhea Management? Rambam Maimonides Med J 2021;12 (1):eoo02. Review. doi:10.5041/RMMJ.10422

Copyright: (C) 2020 Senderovich and Vierhout. This is an open-access article. All its content, except where otherwise noted, is distributed under the terms of the Creative Commons Attribution License (http://creativecommons.org/licenses/by/3.o), which permits unrestricted use, distribution, and reproduction in any medium, provided the original work is properly cited. [This article was published online first at https://www.rmmj.org.il on October 15, 2020.]

Acknowledgements: The authors would like to acknowledge Donald Wang (University of Toronto, Faculty of Medicine) and Amanda Jass (York University) for their writing support with this manuscript.

Conflict of interest: No potential conflict of interest relevant to this article was reported.

* To whom correspondence should be addressed. E-mail: hsenderovich@baycrest.org 
bismuth as an adjunct therapy for diarrhea management in an array of conditions, especially in the palliative care setting.

KEY WORDS: Bismuth, diarrhea, inflammatory bowel diseases, quality of life

\section{INTRODUCTION}

Diarrhea is an ailment associated with the symptoms of frequent bowel movements, loose stools, and abdominal discomfort. ${ }^{1}$ This illness affects both the developed and developing world. ${ }^{2}$ Due to the spectrum of its causes, especially in the palliative care (PC) setting, symptomatic therapy is a sensible approach when illness evaluation is still ongoing, when the diagnosis is lacking clear-cut treatment, or when effective treatment cannot otherwise be attained. ${ }^{3}$ Heavily centered on symptom relief, symptomatic therapy may be used in multiple settings of patient illness, especially PC. Chronic diarrhea has the potential to lower the quality of life of sufferers, ${ }^{3}$ which is of significant importance in PC, hence warranting effective management of its symptoms. Bismuth has the potential to alleviate chronic diarrhea and can be an effective symptomatic treatment in the PC setting.

There is a wide array of diarrheal causes, including viral, bacterial, and parasitic infections, irritable bowel syndrome, cancer, chemotherapy, and as a side effect of antibiotic therapy. ${ }^{4}$ Diarrhea is also known to be a main symptom of microscopic colitis (MC), ${ }^{-7}$ which is a chronic inflammatory disease of the colon with a prevalence of 21-24.7 cases per 100,000 person years in the population. 8 This disease is becoming a more prevalent focus for gastroenterologists, and there has been an enhanced rate of detection. 5 Bismuth has been observed to have positive outcomes on diarrhea caused by MC..$^{-7}$ Bismuth has also been a longstanding therapy for the treatment of gastrointestinal symptoms. 9 As a derivative of salicylic acid, bismuth subsalicylate (BSS) has antibacterial properties, 7,10 making it suitable and effective as a treatment for MC-induced and other forms of diarrhea. However, it is not available in all countries due to risks of long-term toxicity.

In PC settings, symptomatic therapy is an emphasized priority. Diarrhea is especially dangerous in this setting, as terminally ill patients are already compromised and are at increased risk for malnutri- tion, dehydration, electrolyte loss, and fatigue. ${ }^{11,12}$ Various factors may contribute to diarrhea in PC, especially side effects of treatment for the primary illness. ${ }^{13,14}$ Symptom and pain relief are ranked high in the top indicators for improved quality of life in PC. ${ }^{15}$ Based on the literature, some of bismuth's applications relate to the management of diarrhea of different etiologies (including traveler's diarrhea, gastrointestinal infection, MC, irritable bowel syndrome, surgery, and non-specific diarrhea). However, it can be used in cancer and chemotherapy as a symptomatic therapy, indicating a beneficial role of bismuth in PC, which merits further exploration.

Overall, there is limited previous literature on the use of bismuth in diarrhea management, especially in the field of PC. Our paper offers novelty in the field as it explores diarrhea management with bismuth in multiple settings, including applications of bismuth as a symptomatic therapy in PC. This is applicable to clinical issues related to diarrhea and may offer insight into management options when a first-line option has been ineffective or contraindicated.

This narrative review therefore examines the role of bismuth in management of diarrheal symptoms in various settings, with a focus on MC-induced diarrhea. The properties of bismuth with regard to its advantages in the management of multifactorial diarrhea will be discussed in light of the literature.

\section{METHODS}

Searches were performed on PubMed (including Medline) and Embase (Elsevier) for recent studies on "bismuth" OR "bismuth subsalicylate" AND "diarrhea," between January 1980 and September 2019. All searches were also limited to "English language," "human," and "clinical trial." This yielded over 600 results, including reviews, case reports, letters to the editor, book chapters, animal studies, clinical trials, and randomized control trials. The search was further narrowed (Figure 1), and specific inclusion/exclusion criteria (Table 1) were applied. 


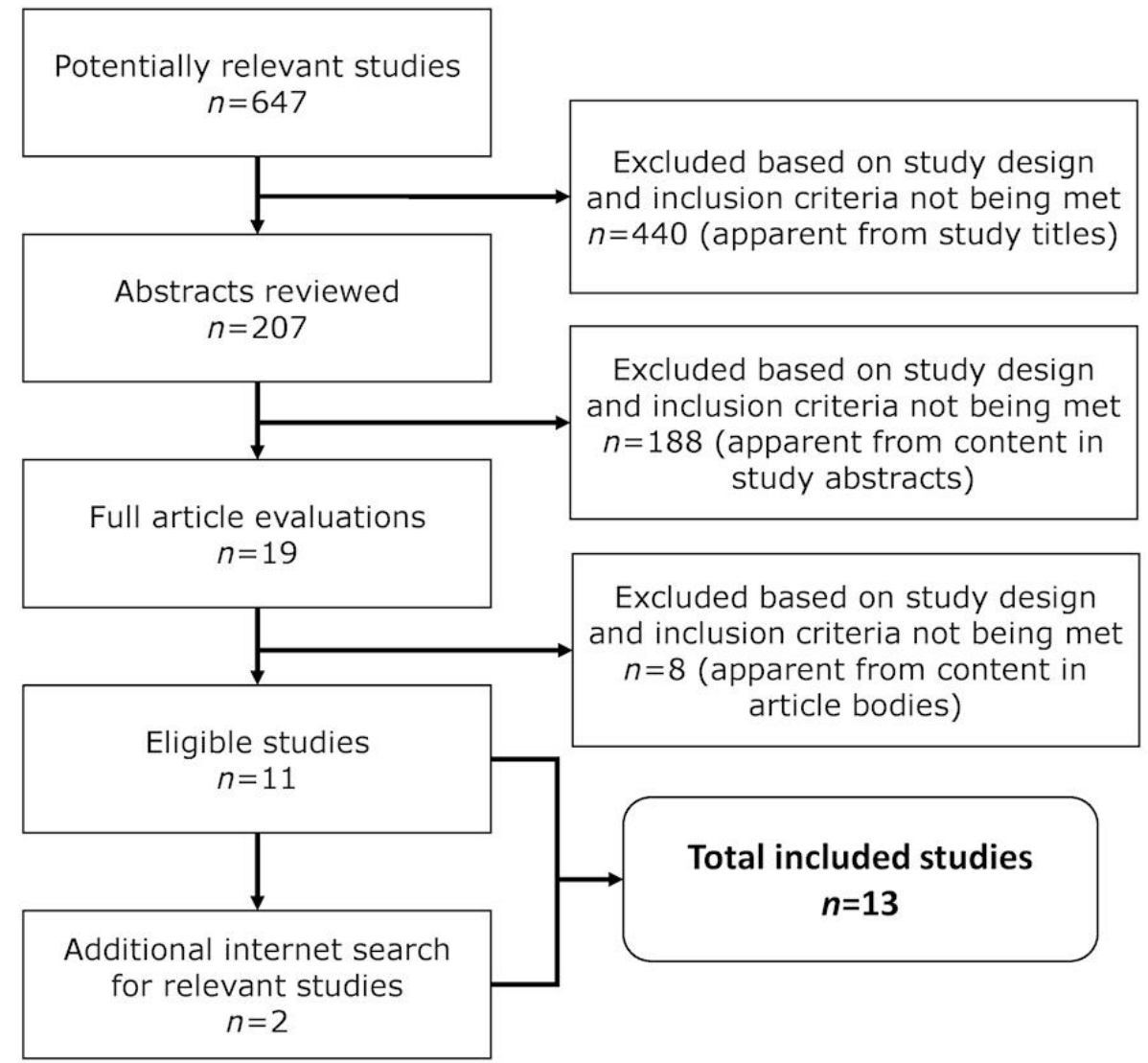

Figure 1. Breakdown of Study Selection.

A detailed breakdown of the numbers for potentially relevant studies, abstracts reviewed, full article evaluations, and eligible studies obtained from PubMed and Embase literature searches.

Table 1. Inclusion and Exclusion Criteria for Reviewed Studies.

\begin{tabular}{|l|l|}
\hline Inclusion Criteria & \multicolumn{1}{c|}{ Exclusion Criteria } \\
\hline English language & Language other than English \\
\hline $\begin{array}{l}\text { Studies involving human subjects } \\
\text { Primary studies }\end{array}$ & Animal studies \\
Studies involving adults $(\geq 18 y)$ & Non-primary articles \\
& $\begin{array}{l}\text { Studies involving children and } \\
\text { participants under } 18 \text { years of age }\end{array}$ \\
$\begin{array}{l}\text { Studies with statistically significant } \\
\text { findings }(P<0.05)\end{array}$ & $\begin{array}{l}\text { Studies without statistically significant } \\
\text { findings }\end{array}$ \\
$\begin{array}{l}\text { Studies including development of } \\
\text { diarrhea, diarrheal incidence, or stool } \\
\text { frequency as an outcome }\end{array}$ & Studies focused on Helicobacter pylori \\
\hline
\end{tabular}


Additional papers were located from the references of papers and additional general Internet searches using Google, Google Scholar, and Caresearch, and the above strategies. Additional searches were performed for specific topics, such as diarrhea and PC, to locate topics not directly related to bismuth and diarrhea.

All studies were reviewed by two independent reviewers to determine their eligibility. Only pri- mary studies conducted on human subjects with observed parameters directly related to diarrhea were included. These included prospective, retrospective, randomized double-blind (RDB), and placebocontrolled studies. Review articles and commentaries were not included. In all studies, bismuth was a main form of intervention being trialed. Eligible studies were read and summarized, and the study design, population, parameters observed, and outcomes documented (Table 2).

Table 2. Relevant Studies Involving Bismuth in Diarrhea Management.

\begin{tabular}{|c|c|c|c|c|}
\hline $\begin{array}{l}\text { Author (Year), } \\
\text { Reference }\end{array}$ & Study Design & Population & $\begin{array}{l}\text { Parameters } \\
\text { Observed }\end{array}$ & Conclusions \\
\hline $\begin{array}{l}\text { Fine \& Lee } \\
(1998)^{5}\end{array}$ & $\begin{array}{l}\text { Prospective } \\
\text { cohort }\end{array}$ & $\begin{array}{l}13 \text { MC patients ( } 7 \\
\text { with subepithelial } \\
\text { collagen deposition } \\
\text { and } 6 \text { without) }\end{array}$ & $\begin{array}{l}\text { Stool, histological } \\
\text { analysis, blood tests }\end{array}$ & $\begin{array}{l}\text { Eight-week BSS treatment } \\
\text { is an effective } \\
\text { intervention for MC }\end{array}$ \\
\hline $\begin{array}{l}\text { Gentile et al. } \\
(2015)^{16}\end{array}$ & Retrospective & $64 \mathrm{MC}$ patients & $\begin{array}{l}\text { Response rate based } \\
\text { on baseline diarrhea } \\
\text { severity }\end{array}$ & $\begin{array}{l}\text { MC patients treated with } \\
\text { BSS had a strong response } \\
\text { rate, but they were also at } \\
\text { high risk to have } \\
\text { recurrence }\end{array}$ \\
\hline $\begin{array}{l}\text { Steffen et al. } \\
(1988)^{17}\end{array}$ & $\begin{array}{l}\text { RDB, parallel } \\
\text { study }\end{array}$ & $\begin{array}{l}245 \text { tourists with } \\
\text { traveler's diarrhea }\end{array}$ & $\begin{array}{l}\text { Stool timing, stool } \\
\text { consistency, number } \\
\text { of stools, relief of } \\
\text { therapy timing }\end{array}$ & $\begin{array}{l}\text { BSS was well tolerated and } \\
\text { effective in shortening the } \\
\text { duration of traveler's } \\
\text { diarrhea }\end{array}$ \\
\hline $\begin{array}{l}\text { Steffen et al. } \\
(1986)^{18}\end{array}$ & RDB study & $\begin{array}{l}390 \text { travelers (aged } \\
16-70 \text { y) going to a } \\
\text { developing country }\end{array}$ & $\begin{array}{l}\text { Incidence of } \\
\text { diarrhea, } \\
\text { microbiological } \\
\text { results }\end{array}$ & $\begin{array}{l}\text { Incidence of diarrhea in } \\
\text { the treatment groups was } \\
\text { significantly lower than in } \\
\text { the placebo group, and } \\
\text { bacteria was only found in } \\
\text { the stools of the placebo } \\
\text { group }\end{array}$ \\
\hline $\begin{array}{l}\text { DuPont et al. } \\
(1987)^{19}\end{array}$ & $\begin{array}{l}\text { Randomized, } \\
\text { placebo- } \\
\text { controlled } \\
\text { trial }\end{array}$ & $\begin{array}{l}182 \text { students from } \\
\text { USA in Mexico }\end{array}$ & $\begin{array}{l}\text { Development of } \\
\text { diarrheal illness, } \\
\text { occurrence of mild } \\
\text { illness, protection } \\
\text { rate, pathogen in } \\
\text { stool }\end{array}$ & $\begin{array}{l}\text { Overall, BSS was an } \\
\text { effective and safe } \\
\text { treatment to reduce the } \\
\text { occurrence of traveler's } \\
\text { diarrhea }\end{array}$ \\
\hline $\begin{array}{l}\text { DuPont et al. } \\
(1980)^{20}\end{array}$ & $\begin{array}{l}\text { RDB placebo- } \\
\text { controlled } \\
\text { study }\end{array}$ & $\begin{array}{l}150 \text { students } \\
\text { traveling to Mexico }\end{array}$ & $\begin{array}{l}\text { Occurrence of } \\
\text { diarrhea, mild } \\
\text { changes in stool } \\
\text { form, } \\
\text { enteropathogen } \\
\text { detection }\end{array}$ & $\begin{array}{l}\text { There was a protective } \\
\text { effect of BSS on } \\
\text { occurrence of diarrhea } \\
\text { and infection with } \\
\text { enteropathogens }\end{array}$ \\
\hline $\begin{array}{l}\text { Johnson et al. } \\
(1986)^{21}\end{array}$ & $\begin{array}{l}\text { Randomized } \\
\text { trial }\end{array}$ & $\begin{array}{l}296 \text { adult students } \\
\text { diagnosed with } \\
\text { acute diarrhea }\end{array}$ & $\begin{array}{l}\text { Number of unformed } \\
\text { stools by hour, } \\
\text { response to therapy, } \\
\text { symptomatic relief }\end{array}$ & $\begin{array}{l}\text { For treatment of traveler's } \\
\text { diarrhea, loperamide is an } \\
\text { effective alternative to } \\
\text { BSS; the median number } \\
\text { of unformed stools was } \\
\text { less in subjects taking } \\
\text { loperamide compared to } \\
\text { BSS }\end{array}$ \\
\hline
\end{tabular}

Continued (next page). 
Table 2 (continued).

\begin{tabular}{|c|c|c|c|c|}
\hline $\begin{array}{c}\text { Author (Year), } \\
\text { Reference }\end{array}$ & Study Design & Population & $\begin{array}{l}\text { Parameters } \\
\text { Observed }\end{array}$ & Conclusions \\
\hline $\begin{array}{l}\text { Graham et al. } \\
(1983)^{22}\end{array}$ & $\begin{array}{l}\text { RDB placebo- } \\
\text { controlled } \\
\text { study }\end{array}$ & $\begin{array}{l}32 \text { healthy volunteers } \\
\text { inoculated with } \\
\text { enterotoxigenic } E \text {. } \\
\text { coli }\end{array}$ & $\begin{array}{l}\text { Development of } \\
\text { diarrhea, } \\
\text { symptomatic } \\
\text { response, stool } \\
\text { weight, stool } \\
\text { frequency, antibody } \\
\text { titer }\end{array}$ & $\begin{array}{l}\text { BSS can be effective in } \\
\text { prevention of traveler's } \\
\text { diarrhea }\end{array}$ \\
\hline $\begin{array}{l}\text { Hansen \& } \\
\text { Penkowa } \\
(2017)^{23}\end{array}$ & $\begin{array}{l}\text { RDB, } \\
\text { prospective } \\
\text { pilot study }\end{array}$ & $\begin{array}{l}50 \text { hematological } \\
\text { inpatients }\end{array}$ & $\begin{array}{l}\text { Duration of diarrhea } \\
\text { and gender-linked } \\
\text { incidence }\end{array}$ & $\begin{array}{l}\text { In lymphoma patients, } \\
\text { bismuth significantly } \\
\text { reduces diarrhea relative } \\
\text { to placebo }\end{array}$ \\
\hline $\begin{array}{l}\text { Zaveri et al. } \\
(2018)^{24}\end{array}$ & $\begin{array}{l}\text { Prospective } \\
\text { RDB, } \\
\text { placebo- } \\
\text { controlled, } \\
\text { crossover } \\
\text { study }\end{array}$ & $\begin{array}{l}36 \text { patients with } \\
\text { flatus and/or stool } \\
\text { odor changes who } \\
\text { were at least } 6 \\
\text { months post-loop } \\
\text { duodenal switch }\end{array}$ & $\begin{array}{l}\text { Gastrointestinal } \\
\text { Quality of Life Index } \\
\text { (GIQLI) } \\
\text { questionnaire }\end{array}$ & $\begin{array}{l}\text { For the treatment group } \\
\text { GIQLI overall scores and } \\
\text { digestive scores were } \\
\text { significantly higher after } \\
\text { treatment; quality of life } \\
\text { after the treatment with } \\
\text { bismuth was significantly } \\
\text { higher compared to pre- } \\
\text { treatment and post- } \\
\text { placebo }\end{array}$ \\
\hline $\begin{array}{l}\text { Daghaghzadeh, } \\
\text { et al. }(2018)^{25}\end{array}$ & $\begin{array}{l}\text { Placebo- } \\
\text { controlled } \\
\text { clinical trial }\end{array}$ & $\begin{array}{l}129 \text { IBS patients with } \\
\text { three subtypes: IBS- } \\
\text { constipation } \\
\text { dominant (IBS-C), IBS- } \\
\text { diarrhea dominant } \\
\text { (IBS-D), and IBS- } \\
\text { mixed (IBS-M) }\end{array}$ & $\begin{array}{l}\text { IBS-related } \\
\text { questionnaires, IBS- } \\
\text { severity scoring } \\
\text { system }\end{array}$ & $\begin{array}{l}\text { Quality of life significantly } \\
\text { improved in IBS-D from } \\
\text { study beginning to end; } \\
\text { bismuth had a significant } \\
\text { effect on improvement of } \\
\text { IBS-D patient symptoms }\end{array}$ \\
\hline $\begin{array}{l}\text { Hernández et } \\
\text { al. }(2015)^{26}\end{array}$ & $\begin{array}{l}\text { Prospective, } \\
\text { observational } \\
\text { study }\end{array}$ & $\begin{array}{l}65 \text { patients } \\
\text { undergoing } \\
\text { biliopancreatic } \\
\text { diversion with } \\
\text { Scopinaro's classic } \\
\text { technique }\end{array}$ & $\begin{array}{l}\text { Gastrointestinal } \\
\text { Quality of Life Index } \\
\text { (GIQLI) } \\
\text { questionnaire, } \\
\text { nutritional status }\end{array}$ & $\begin{array}{l}\text { All domains of the GIQLI } \\
\text { were significantly higher } \\
\text { after bismuth treatment } \\
\text { than before treatment; in } \\
\text { patients undergoing } \\
\text { Scopinaro's biliopancreatic } \\
\text { diversion, bismuth } \\
\text { subgallate was effective } \\
\text { for short-term treatment } \\
\text { of unfavorable symptoms }\end{array}$ \\
\hline $\begin{array}{l}\text { DuPont et al. } \\
(1990)^{27}\end{array}$ & $\begin{array}{l}\text { Open-label, } \\
\text { parallel } \\
\text { comparison } \\
\text { study }\end{array}$ & $\begin{array}{l}203 \text { adult students } \\
\text { from USA or Mexico } \\
\text { diagnosed as having } \\
\text { acute, non-specific } \\
\text { diarrhea }\end{array}$ & $\begin{array}{l}\text { Average number of } \\
\text { unformed stools, } \\
\text { stool frequency, } \\
\text { time to last } \\
\text { unformed stool } \\
\text { (TTLUS), time to } \\
\text { first unformed stool } \\
\text { (TTFUS), percent of } \\
\text { participants with no } \\
\text { additional loose } \\
\text { stools and requiring } \\
\text { no additional doses }\end{array}$ & $\begin{array}{l}\text { Loperamide is more } \\
\text { effective for acute non- } \\
\text { specific diarrhea relief } \\
\text { than BSS; mean TTLUS was } \\
\text { lower for loperamide and } \\
\text { median TTFUS was longer; } \\
\text { loperamide patients } \\
\text { overall required fewer } \\
\text { doses compared to BSS } \\
\text { patients }\end{array}$ \\
\hline
\end{tabular}

BSS, bismuth subsalicylate; IBS, irritable bowel syndrome; MC, microscopic colitis; RDB, randomized double-blind. 


\section{Case Vignettes}

Three demonstrative case vignettes were also developed to illustrate potential applications of bismuth in clinical settings. The vignettes presented below involve multifactorial origin of diarrhea, where treatment with bismuth could be attempted. We then aligned the vignettes with the findings of this review, supported by references.

\section{Vignette 1}

This patient was a male in his 6os with a longstanding history of MC. He was a resident of longterm care (LTC) and was bed-bound. He presented with loose bowel movements (BM), five to six times/ day, in addition to other comorbidities such as anxiety and irritable bowel syndrome. His medications included sulfasalazine, budesonide, mirtazapine, gabapentin, and ferrous fumarate.

The patient utilized loperamide for a long time prior to admission to LTC, with some response. Following LTC, resins such as cholestyramine were attempted with partial relief of symptoms, reducing BM frequency to three or four times daily, but requiring a large volume of fluids with each cholestyramine dose. This led to poor cholestyramine adherence, and BM were only partially controlled. He could not tolerate budesonide and developed syncope. Bismuth was introduced at an initial dosage of $262 \mathrm{mg}$ orally once per day, and then titrated up to $524 \mathrm{mg}$ four times a day $(2,096$ $\mathrm{mg}$ total daily). Bowel movement frequency decreased to once or occasionally twice daily, and the patient stabilized. His mood, as well as quality of life, significantly improved. A bout of aspiration pneumonia and antibiotic treatment led to relapse of diarrhea while being off bismuth; bismuth was resumed for another month. No exacerbation of MC was noted during that time. The bismuth was titrated down during the next three months to 120 mg orally twice daily, and despite the reduction his $\mathrm{BM}$ remained under control. Alternation of bismuth intake continued for the patient, with a one-month break in bismuth treatment, following by three months of bismuth, $120 \mathrm{mg}$ orally twice daily; no recurrence of diarrhea was noted, resulting in improved quality of life.

\section{Vignette 2}

This patient was a female in her 9os residing in the PC unit of a LTC facility. She had a history of loose $\mathrm{BM}$ five to six times daily and multiple comorbidities including lymphoma. Her medications included ferrous fumarate, duloxetine, and hydromorphone. Mood management was challenging as mood fluctuated on a daily basis and was closely related to her BM pattern. Loose BM and abdominal discomfort restricted her ability to participate and attend recreational activities that she had previously enjoyed. In addition, she was experiencing repeated falls secondary to orthostasis, and possible dehydration induced by the high frequency of diarrhea. Her care goals were comfort and symptom control with a priority for quality of remaining life.

Bismuth was introduced at 1,000 mg twice a day for five days orally; the patient soon stabilized without any negative sequelae. Her mood improved, and she was able to preserve her quality of life. Bismuth was titrated down then to $500 \mathrm{mg}$ twice a day for the next 10 days, and she remained stable. No worsening symptoms were noted. Treatment was stopped when oral intake was lost and she approached end of life.

\section{Vignette 3}

This patient was a female in her 80 s being cared for in a PC unit of a LTC facility. She had a history of recto-sigmoid cancer with severe diarrhea-14 to 16 BM daily. She had undergone radiation therapy complicated by radiation proctitis two years prior to admission. Unfortunately, the tumor continued to progress. Her medications included ferrous fumarate, proton pump inhibitors, hydromorphone, and tranexamic acid. The patient's behavior shifted daily with restlessness and agitation frequently observed, which appeared to be related to BM frequency. The discomfort associated with her diarrhea restricted her ability to participate in events that brought joy and added value to her life. In addition, she was experiencing frequent melena, and persistent severe uncontrollable diarrhea that was escalating the intensity of rectal bleeding. Patient 3 became increasingly fatigued, was emotionally depressed due to the lack of improvement in her condition, and her quality of life was significantly reduced.

Bismuth 1,000 mg twice a day for five days was attempted, and she stabilized soon after. However, the patient also developed tremor, visual hallucinations, severe nausea, blackening of the tongue and stool, and began to decline rapidly cognitively. Bismuth was reduced to $500 \mathrm{mg}$ twice a day, with only partial symptom improvement: tremor and visual hallucinations ceased, but blackening of the tongue and stool persisted and severe nausea continued to negatively impact quality of life. Bismuth was dis- 
continued, thereby resolving the nausea and blackening of the tongue and stool, but there was a recurrence of her diarrhea.

Charcoal, 262 mg orally once daily, was initiated, in addition to octreotide $900 \mathrm{mg}$ daily divided in three doses. Frequency and consistency of BM improved; soon after the octreotide was discontinued, while charcoal was titrated up to an oral amount of six doses daily. Bowel movement frequency decreased to four to five times daily, and its consistency changed from loose to soft. With the diarrhea no longer disturbing her, the patient's mood and behavior improved, as well as the quality of her life.

\section{RESULTS}

Thirteen studies were found to be relevant to the objective at hand; these are listed in Table 2. Eleven of these studies were located utilizing PubMed and Embase, and two were found with additional general Internet searches. These studies focused on the utilization of bismuth in various settings, including two studies on MC,5,16 five on traveler's diarrhea, ${ }^{17-21}$ and one each on gastrointestinal infection, ${ }^{22}$ chemotherapy and cancer, ${ }^{23}$ loop duodenal switch, ${ }^{24}$ irritable bowel syndrome, ${ }^{25}$ Scopinaro's biliopancreatic diversion, ${ }^{26}$ and acute, non-specific diarrhea. ${ }^{27}$ The majority of studies found bismuth to be beneficial in diarrhea management. Two studies compared loperamide and bismuth and found loperamide to be more effective for acute diarrhea and traveler's diarrhea. ${ }^{21,27}$

\section{DISCUSSION}

\section{Mechanism of Action}

The exact antidiarrheal mechanism of action has not yet been determined for bismuth. However, BSS is thought to have antidiarrheal action through antisecretory, antibacterial, and anti-inflammatory operations, as it is a derivative of salicylic acid.7,28 Bismuth has been seen to promote fluid and electrolyte absorption across the intestinal tract, ${ }^{28}$ and significantly inhibit fluid accumulation in the intestinal lumen. ${ }^{29}$ By reducing the amount of free fluid, diarrheal symptoms are ameliorated. Bismuth is also described to have adsorbent properties. ${ }^{29} \mathrm{~A}$ study observing the effects of bismuth on the various bacterial pathogens of Clostridium difficile, Salmonella, Shigella, and Shiga toxin-producing Escherichia coli showed reduced bacterial growth in vitro after treatment with bismuth, compared to untreat- ed control. ${ }^{30}$ Bismuth has also been observed to adhere to the toxins synthesized by E. coli. ${ }^{28}$

\section{Microscopic Colitis}

As mentioned above, $\mathrm{MC}$ is an inflammatory condition of the bowel, which has had an increasing incidence ${ }^{31,32}$ and a growing rate of detection by gastroenterologists. 5 There are two MC subtypes: collagenous colitis, where a thickened subepithelial collagen band is present, and lymphocytic colitis, where it is absent. $5,7,8,31-33$ The exact pathogenesis is unknown 5,7,32,34; however, pathogenic and commensal bacteria 5 as well as autoimmune components are believed to play a role in MC. $5,8,31,32$

\section{Microscopic Colitis and Diarrhea}

Microscopic colitis is a considerably prevalent source of chronic diarrhea, ${ }^{-8,16,31,33}$ and unfortunately this symptom can be extremely wearying to patients. The mechanism of diarrhea in MC is speculated to be attributed to multiple elements, including the severity of the inflammatory response, impairment of electrolyte absorption, and increased secretion..$^{22}$ Additionally, increased levels of prostaglandins in the lumen and mucosa may also be associated with inflammatory diarrhea caused by MC. ${ }^{2}$

In addition to being known to promote fluid and electrolyte absorption in the intestinal tract, ${ }^{28}$ bismuth is able to inhibit prostaglandin synthesis, ${ }^{28}$ and it has both anti-inflammatory and antibacterial properties. For all these reasons, bismuth seems to be an appropriate candidate for treating MC. However, there remains a knowledge gap regarding MC therapy, 5 especially lymphocytic colitis. 33 Commonly used MC drugs include sulfasalazine and mesalamine; however, one of the associated side effects for these drugs is diarrhea itself. 5 Budesonide is the most studied drug for $\mathrm{MC}^{31}$ and is a corticosteroid therapy to which the majority of patients respond. ${ }^{6-8}$ Although it is a first-line therapy, some studies have shown adverse effects, 34 as seen in the case of Vignette 1 where the patient developed syncope, and patients taking budesonide long-term should be monitored. In a study completed by Fine and Lee, 5 bismuth not only reduced the frequency and weight of bowel movements, but also improved stool consistency, and worked at a histopathological level to reduce tissue abnormalities and inflammation. The resolution of inflammation at the histological level by bismuth was also seen in a case study involving collagenous colitis. 35 Gentile et al. ${ }^{16}$ studied both collagenous and lymphocytic colitis 
patients who were treated with bismuth. They found decreased diarrhea severity that was dose-related: higher doses (up to nine tablets daily) were more effective than lower ones, which was also observed in all demonstrative cases (Vignette 1, Vignette 2, and Vignette 3). In all of the MC and bismuth studies reviewed, bismuth reduced diarrhea in MC patients, $5,16,33,35$ which was also seen in the case of Vignette 1.

\section{Traveler's Diarrhea and Gastrointestinal Infection}

Traveler's diarrhea is the most prevalent illness related to travel and is caused by bacterial, viral, or protozoal pathogens. ${ }^{36}$ Approximately $80 \%$ of traveler's diarrhea cases are attributed to bacterial infection, ${ }^{10,37}$ with enterotoxigenic and enteroaggregative $E$. coli being the most common bacterial pathogens involved in all areas except Southeast Asia. ${ }^{6}$ Common viral pathogens include norovirus and rotavirus. ${ }^{36}$ Bismuth can be taken for chemoprevention $^{10,36,37}$ and can prevent up to $65 \%$ of cases of expected traveler's diarrhea. ${ }^{10,36}$ It can also be taken after the onset of traveler's diarrhea and has been shown to reduce diarrhea duration. ${ }^{17}$ In other studies, bismuth prevented the growth of pathogens related to traveler's diarrhea in adults visiting other countries. ${ }^{18,19}$ In another RDB, placebo-controlled study, diarrhea and the presence of enteropathogens in the stool were reduced in subjects taking bismuth. ${ }^{20}$ It is believed that the bactericidal mechanisms of bismuth may involve cell wall degradation, inhibition of plasma membrane function, and prevention of adenosine triphosphate (ATP) synthesis. ${ }^{30}$ These antimicrobial properties suggest the suitability of bismuth for the treatment and prevention of traveler's diarrhea. ${ }^{22}$ However, it should also be noted that a study examining the effects of probiotic Saccharomyces boulardii and bismuth on cholera revealed that neither of the therapies, nor their combination, was suggested as an adjunct treatment for cholera, due to the study being underpowered and lacking statistical significance between study arms..$^{8}$ These pathogens are also of concern for infections in the PC and LTC settings.

\section{Cancer and Chemotherapy}

Cancer-associated diarrhea can be attributed to a multitude of treatment sources, including chemotherapy, signal transduction inhibitors, immunotherapy, radiotherapy, laxatives, surgery, and infection.39,40 Diarrhea can also be a symptom of the cancer itself, such as in adrenal, ${ }^{41}$ pancreatic, ${ }^{42}$ lung neuroendocrine, and colorectal cancers. ${ }^{39}$ Cancer is a common ailment in PC, and many patients may experience diarrhea as a symptom of their illness. This was seen in the case of the patient in Vignette 3 , who experienced severe diarrhea due to her rectosigmoid cancer. This symptom may actually interfere with the cancer treatment itself. ${ }^{0}$ Since bismuth promotes the absorption of fluid ${ }^{28}$ and inhibits fluid accumulation in the intestines, ${ }^{29}$ it is an appropriate proposed therapy for cancer and chemotherapy-induced diarrhea where there is an excess of fluids present. In a RDB, prospective pilot study by Hansen and Penkowa, the effects of bismuth on patients receiving cancer treatment revealed that the duration of diarrhea experienced by lymphoma patients receiving melphalan chemotherapy was decreased as compared to the placebo group. ${ }^{23}$ However, in patients with multiple myeloma, diarrhea persisted irrespective of treatment. ${ }^{23}$ This suggests that the effects of bismuth on cancer-related diarrhea may be contingent on the type of cancer, and that lymphoma patients specifically can benefit from bismuth's antidiarrheal effects, as was seen in the case of the patient in Vignette 2 who suffered from lymphoma.

\section{Side Effects}

Pardi et al. reported that non-specific antidiarrheal agents including bismuth had limited side effects. 33 Several studies reported that bismuth therapy is safe and well-tolerated by patients5,20,23,34; of note is the prospective cohort study of Fine and Lee, confirming this. ${ }^{5}$ In PC settings, patients often have multiple complications and symptoms, therefore treatmentrelated side effects should be avoided. This was seen in Vingette 1, where the patient developed the side effect of syncope with budesonide, but was able to tolerate bismuth well. However, caution should be exercised with chronic use of this medication, especially at high doses, as rare but serious side effects related to neurotoxicity have been reported. These include impaired cognitive function, tremors, myoclonus, visual hallucinations, and gait impairment. 43 Other reports of toxicity include delirium, psychosis, ataxia, and seizures.44 This was seen in the patient of Vignette 3, who experienced cognitive impairment, tremor, and visual hallucinations with the use of bismuth, which required her to discontinue bismuth and begin to take charcoal for diarrhea management. Although bismuth toxicity is very infrequent, awareness should still be promoted due to its severity and the availability of the drug on the market. Furthermore, bismuth should not be given to pa- 
tients with renal impairment, who may experience symptoms of neurotoxicity, neuromuscular spasm, neuromuscular weakness, hearing loss, and gastrointestinal issues induced by bismuth accumulation. 45 Due to the known risk of long-term toxicity, bismuth is unavailable in many countries, ${ }^{31}$ with bismuth subgallate use being restricted in France and banned in Australia. ${ }^{46}$ Additionally, the very ability of bismuth to promote fluid absorption in the intestinal tract could also precipitate constipation in some cases, such as when it is administered as a preventative..$^{18}$ Other non-adverse side effects that have been observed are objectionable taste, ${ }^{18}$ nausea, ${ }^{18}$ and blackening of the tongue and stool. ${ }^{10,36,37}$

\section{Limitation of Use}

Although bismuth appears to be an effective drug for the management of diarrhea, it is not without limitations. For traveler's diarrhea prevention, it must be taken frequently (two to four times per day) ${ }^{36}$ and in a large quantity (eight tablets), ${ }^{47}$ making it a less appealing choice for travelers. It has also been known to compromise the absorption of other medications, including doxycycline for example. 47 Side effects, especially for healthy individuals taking the medication as a preventative measure, such as blackened tongue and tinnitus, also make bismuth use less desirable. 47 Long-term therapy with bismuth raises concerns for adverse side effects and toxicity, including cognitive and gait impairment, tremors, myoclonus, visual hallucinations, delirium, psychosis, ataxia, and seizures.43,44 Bismuth cannot be used in patients with renal impairment. 45 Lastly, studies have also found that loperamide is more effective than bismuth for the management of acute diarrhea $^{26}$ and showed more symptom relief in traveler's diarrhea. ${ }^{21}$ However, bismuth showed effectiveness for traveler's diarrhea in multiple studies, ${ }^{17-20}$ and, unlike loperamide, its safety with comorbid common C. difficile infections in PC settings should be appreciated.

\section{CONCLUSIONS}

In conclusion, this review points to bismuth having suitable potential as a symptomatic therapy for diarrhea. Diarrhea can be a symptom or side effect of many causes, including cancer, chemotherapy, antibiotics, gastrointestinal infections, irritable bowel syndrome, traveler's diarrhea, and MC. Bismuth's anti-inflammatory and antibacterial properties make it a useful therapy in these settings. Additionally, since diarrhea in palliative settings can be multifactorial with many confounding factors, symptomatic therapy, such as through treatment with bismuth, can be a logical approach. Minimal side effects have been associated with bismuth therapy, and serious reactions are rare, making it a suitable option for PC patients experiencing diarrhea. However, chronic use at high doses should be monitored as neurotoxic side effects are a possibility. It should also be noted that bismuth treatment should be used with caution in PC, where patients may have impaired renal function. Overall, the safety and tolerability of bismuth can be appreciated in PC, in the setting of a fragile population with multiple comorbidities and complications. However, it should also be recognized that restriction of bismuth use in some parts of the world is a roadblock for a potentially useful treatment of PC patients in these countries. Further research is required in order to evaluate the efficacy of bismuth in palliative settings, and overall as a therapy for diarrheal illness.

\section{Lessons Learned}

Due to its antisecretory, anti-inflammatory, and antibacterial characteristics, bismuth is equipped with the properties to manage diarrhea from multiple angles. Its overall limited range of adverse side effects makes it an appealing option for patients with numerous comorbidities. Healthcare providers can explore bismuth as an adjunct therapy for diarrhea management in an array of conditions. Interestingly, patients with older age at the time of MC diagnosis are more likely to have a positive outcome when using bismuth than are younger patients, ${ }^{48}$ which also supports the use of bismuth in elderly palliative populations. In infectious diarrhea, bismuth can be added to antibiotic treatment due to its antimicrobial properties. ${ }^{11}$ Clostridium difficile and $E$. coli infection, in both of which bismuth can be utilized, frequently occur at LTC facilities and hospices.49,50 Interestingly enough, in a study conducted on bacterial infection in hospice patients, $E$. coli was found to be the most frequent pathogen. 49 Bismuth offers a viable option as a first-line treatment instead of loperamide, which cannot be used in the case of $C$. difficile infections, common in PC, as it may cause megacolon and escalate the severity of colitis.

\section{Further Research}

Further studies involving clinical evaluation are critical to determining the efficacy and potency of bismuth in the aforementioned settings and conditions. 
Firstly, it would be beneficial to obtain a clearer understanding of the mechanism of action of bismuth, as its exact antidiarrheal mechanism has not been determined. Basic science research should be conducted to elucidate the antidiarrheal mechanism of bismuth, which may also provide further insight and understanding of the appropriate situations for its use.

Although the described studies involve various types of diarrhea, including that caused by MC, traveler's diarrhea, bacterial infection, chemotherapy, duodenal switch, irritable bowel syndrome, and Scopinaro's biliopancreatic diversion, no studies have evaluated the effectiveness of bismuth in palliative settings. It is important to explore the use of bismuth as a symptomatic therapy, such as through randomized control trials, to determine optimal dosing and usage as well as the possible challenges. Further research should also be conducted to better define the barriers associated with bismuth. For example, there is a need to further explore the application of bismuth in patients with renal impairment. Studies are required to investigate the safety of this symptomatic therapy in palliative patients.

Further research is also required to determine the specific types of cancers and associated chemotherapeutics where bismuth may be suitable to manage cancer and chemotherapy-related diarrhea. Additional randomized control and placebo-controlled studies would be beneficial to determine against which other types of bacterial and viral infections bismuth may be effective. This is also applicable to PC, where overall more randomized control trials with larger sample sizes and longer follow-up times are needed to determine the role of bismuth in this setting.

\section{REFERENCES}

1. Thangaraj P. Anti-diarrhoeal Activity. In: Thangaraj P, Rainsford KD, eds. Pharmacological Assays of Plant-Based Natural Products. Cham, Switzerland: Springer International Publishing; 2016:129-30. CrossRef

2. Guerrant RL, Hughes JM, Lima NL, Crane J. Diarrhea in developed and developing countries: magnitude, special settings, and etiologies. Rev Infect Dis 1990;12:S41-50. $\underline{\text { CrossRef }}$

3. Bonis PAL, Lamont JT. Approach to the adult with chronic diarrhea in resource-rich settings. UpToDate website. Last updated 2020; January 13. Available at: https://www.uptodate.com/contents/approach-to- the-adult-with-chronic-diarrhea-in-resource-richsettings (accessed February 1, 2020).

4. Corinaldesi R, Stanghellini V, Barbara G, Tomassetti P, De Giorgio R. Clinical approach to diarrhea. Intern Emerg Med 2012;7:255-62. CrossRef

5. Fine KD, Lee EL. Efficacy of open-label bismuth subsalicylate for the treatment of microscopic colitis. Gastroenterology 1998;114:29-36. CrossRef

6. Park T, Cave D, Marshall C. Microscopic colitis: a review of etiology, treatment and refractory disease. World J Gastroenterol 2015;21:8804. CrossRef

7. Jauregui-Amezaga A, Vermeire S, Geboes K. Contemporary methods for the diagnosis and treatment of microscopic colitis. Exp Rev Gastroenterol Hepatol 2016;10:47-61. CrossRef

8. Cotter TG, Pardi DS. Current approach to the evaluation and management of microscopic colitis. Curr Gastroenterol Rep 2017;19:8. CrossRef

9. Dupont HL. Bismuth subsalicylate in the treatment and prevention of diarrheal disease. Drug Intell Clin Pharm 1987;21:687-93. CrossRef

10. DuPont HL. Travelers' diarrhea: antimicrobial therapy and chemoprevention. Nat Clin Pract Gastroenterol Hepatol 2005;2:191-8. CrossRef

11. Alderman J. Diarrhea in palliative care. J Palliat Med 2005;8:449-50. CrossRef

12. Mercadante S. Diarrhea in terminally ill patients: pathophysiology and treatment. J Pain Symptom Manage 1995;10:298-309.

13. Cherny NI. Evaluation and management of treatmentrelated diarrhea in patients with advanced cancer: a review. J Pain Symptom Manage 2008;36:413-23. CrossRef

14. Balducci L, Dolan D, Hoffe SE. Palliative care in older patients with cancer. Cancer Control 2015;22:480-8. CrossRef

15. Claessen SJJ, Francke AL, Belarbi HE, Pasman HRW, van der Putten MJA, Deliens L. A new set of quality indicators for palliative care: process and results of the development trajectory. J Pain Symptom Manage 2011;42:169-82. $\underline{\text { CrossRef }}$

16. Gentile NM, Khanna S, Loftus EV, Tremaine WJ, Kammer PP, Pardi DS. Su1353 outcomes of patients with microscopic colitis treated with bismuth subsalicylate. Gastroenterology 2015;148:S-483. CrossRef

17. Steffen R, Mathewson JJ, Ericsson CD, et al. Travelers' diarrhea in West Africa and Mexico: fecal transport systems and liquid bismuth subsalicylate for self-therapy. J Infect Dis 1988;157:1008-13. CrossRef

18. Steffen R, DuPont H, Heusser R, et al. Prevention of traveler's diarrhea by the tablet form of bismuth sub- 
salicylate. Antimicrob Agents Chemother 1986;29: 625-7. CrossRef

19. DuPont HL, Ericsson CD, Johnson PC, et al. Prevention of travelers' diarrhea by the tablet formulation of bismuth subsalicylate. JAMA 1987;257:1347-50. CrossRef

20. DuPont HL, Sullivan P, Evans DG, et al. Prevention of traveler's diarrhea (emporiatric enteritis): prophylactic administration of subsalicylate bismuth. JAMA 1980;243:237-41. CrossRef

21. Johnson PC, Ericsson CD, DuPont HL, et al. Comparison of loperamide with bismuth subsalicylate for the treatment of acute travelers' diarrhea. JAMA 1986; 255:757-60. $\underline{\text { CrossRef }}$

22. Graham DY, Estes MK, Gentry LO. Double-blind comparison of bismuth subsalicylate and placebo in the prevention and treatment of enterotoxigenic Escherichia coli-induced diarrhea in volunteers. Gastroenterology 1983;85:1017-22. CrossRef

23. Hansen PB, Penkowa M. Bismuth adjuvant ameliorates adverse effects of high-dose chemotherapy in patients with multiple myeloma and malignant lymphoma undergoing autologous stem cell transplantation: a randomised, double-blind, prospective pilot study. Support Care Cancer 2017;25:1279-89. CrossRef

24. Zaveri H, Surve A, Cottam D, et al. Does bismuth subgallate affect smell and stool character? A randomized double-blinded placebo-controlled trial of bismuth subgallate on loop duodenal switch patients with complaints of smelly stools and diarrhea. Obes Surg 2018;28:3511-17. CrossRef

25. Daghaghzadeh H, Memar A, Mohamadi Y, et al. Therapeutic effects of low-dose bismuth subcitrate on symptoms and health-related quality of life in adult patients with irritable bowel syndrome: a clinical trial. J Res Pharm Pract 2018;7:13-21. CrossRef

26. Hernández JRH, Rizzo JF, Díaz YC, Bubi ED, Cabrillana JM, Fernández EML-T. Effect of bismuth subgallate on the quality of life in patients undergoing Scopinaro's biliopancreatic diversion. Surg Obes Relat Dis 2015;11:436-41. CrossRef

27. DuPont HL, Sanchez JF, Ericsson CD, et al. Comparative efficacy of loperamide hydrochloride and bismuth subsalicylate in the management of acute diarrhea. Am J Med 1990;88:S15-19. CrossRef

28. National Library of Medicine National Center for Biotechnology Information. Compound Summary: Bismuth subsalicylate. Updated August 9, 2020. Available at: https://pubchem.ncbi.nlm.nih.gov/ compound/16682734 (accessed August 11, 2020).
29. Ericsson CD, Tannenbaum C, Charles TT. Antisecretory and antiinflammatory properties of bismuth subsalicylate. Rev Infect Dis 1990;12:S16-20. CrossRef

30. Pitz AM, Park GW, Lee D, Boissy YL, Vinjé J. Antimicrobial activity of bismuth subsalicylate on Clostridium difficile, Escherichia coli O157: H7, norovirus, and other common enteric pathogens. Gut Microbes 2015;6:93-100. $\underline{\text { CrossRef }}$

31. Wenzl HH. Diarrhea in chronic inflammatory bowel diseases. Gastroenterol Clin North Am 2012;41:65175. CrossRef

32. Pardi DS, Kelly CP. Microscopic colitis. Gastroenterology 2011;140:1155-65. CrossRef

33. Pardi DS, Ramnath VR, Loftus Jr EV, Tremaine WJ, Sandborn WJ. Lymphocytic colitis: clinical features, treatment, and outcomes. Am J Gastroenterol 2002; 97:2829-33. CrossRef

34. Chande N, McDonald JWD, MacDonald JK. Interventions for treating collagenous colitis. Cochrane Database Syst Rev 2008;(2):CDo03575. CrossRef

35. Amaro R, Poniecka A, Rogers AI. Case report: collagenous colitis treated successfully with bismuth subsalicylate. Dig Dis Sci 2000;45:1447-50. CrossRef

36. Giddings SL, Stevens AM, Leung DT. Traveler's diarrhea. Med Clin North Am 2016;100:317-30. CrossRef

37. Lloyd R, Bennett C. Travellers' diarrhoea: causes, prevention and treatment. Nurs Stand 2012;26:51-6. CrossRef

38. Sheele J, Cartowski J, Dart A, et al. Saccharomyces boulardii and bismuth subsalicylate as low-cost interventions to reduce the duration and severity of cholera. Pathog Glob Health 2015;109:275-82. CrossRef

39. Bossi P, Antonuzzo A, Cherny N, et al. Diarrhoea in adult cancer patients: ESMO Clinical Practice Guidelines. Ann Oncol 2018;29:iv126-42. CrossRef

40. Ippoliti C. Antidiarrheal agents for the management of treatment-related diarrhea in cancer patients. Am J Health Syst Pharm 1998;55:1573-80. CrossRef

41. Trump DL, Livingston JN, Baylin SB. Watery diarrhea syndrome in an adult with ganglioneuromapheochromocytoma. Identification of vasoactive intestinal peptide, calcitonin, and catecholamines and assessment of their biologic activity. Cancer 1977;40: 1526-32. $\underline{\text { CrossRef }}$

42. Marks IN, Bank S, Louw JH. Islet cell tumor of the pancreas with reversible watery diarrhea and achlorhydria. Gastroenterology 1967;52:695-708. CrossRef

43. Masannat Y, Nazer E. Pepto bismuth associated neurotoxicity: a rare side effect of a commonly used medication. W V Med J 2013;109:32-4. 
44. Gordon MF, Abrams RI, Rubin DB, et al. Bismuth subsalicylate toxicity as a cause of prolonged encephalopathy with myoclonus. Mov Disord 1995;10:2202. $\underline{\text { CrossRef }}$

45. Khim LL, Yi TW. A case report of an end-stage renal failure patient with peptic ulcer disease. The Singapore Family Physician 2017;43:51-5.

46. Marshall BJ. The use of bismuth in gastroenterology. The ACG Committee on FDA-related Matters. American College of Gastroenterology. Am J Gastroenterol 1991;86:16-25.

47. Casburn-Jones AC, Farthing MJG. Management of infectious diarrhoea. Gut 2004;53:296-305. CrossRef
48. Colussi D, Salari B, Stewart KO, et al. Clinical characteristics and patterns and predictors of response to therapy in collagenous and lymphocytic colitis. Scand $\mathrm{J}$ Gastroenterol 2015;50:1382-8. CrossRef

49. Vitetta L, Kenner D, Sali A. Bacterial infections in terminally ill hospice patients. J Pain Symptom Manage 2000;20:326-34. CrossRef

50. Simor AE, Yake SL, Tsimidis K. Infection due to Clostridium difficile among elderly residents of a longterm-care facility. Clin Infect Dis 1993;17:672-8. CrossRef 